\title{
Educating the New Soviet Man: Propagated Image and Hidden Resistance in Soviet Latvia ${ }^{1}$
}

Iveta Kestere ${ }^{a}$

\section{Manuel Joaquín Fernández González $^{b}$}

a Vilnius University, Faculty of Philosophy iveta.kestere@lu.lv

b University of Latvia, Faculty of Education, Psychology and Art

manuels.fernandezs@lu.lv

Received 31 March 2021

Accepted 27 April 2021

Available online 31 August 2021

DOI 10.15240/tul/006/2021-1-001
Abstract The New Soviet Man has been studied primarily from the perspective of its creators, propagators of Communist ideology, while the recipients of the New Soviet Man project and its immediate end users, namely pupils and teachers were largely ignored. Hence, the present research, while capturing and utilizing the experience of Soviet Latvia from 1945 to 1985 , sets the research questions as to how the image of the New Soviet Man was presented and introduced at schools and how the concept of the New Soviet Man was perceived and utilised by the "objects" of this state contract - teachers and pupils. The research corpus includes 26 textbooks, 265 school photos and 367 student profile records. For the research purposes, four

discursive domains of the New Soviet Man project were identified, namely, socio-biological discourse (gender, body, sexuality and health); social discourse (social class); spatial discourse (nationality) and discourse of individuality (personality, character traits). Given that the dictatorship unavoidably engenders the conflict of interests and resistance, the research corpus allowed to detect some tiny openings for the oppressed to express their views, some elements of pupils' and teachers' subtle resistance to the creation of the New Soviet Man, by using horizontal solidarity, avoidance, and slipping into the Grey Zone.

Keywords New Soviet Man, propaganda, hidden resistance, Soviet education

1 The research is part of the project "Raising of the 'New Man' in Soviet schools: the case of Lithuania” funded by Research Council of Lithuania, LMTLT, agreement No. S-LIP-19-68/ (1.78) SU-810 and of the ERDF funded postdoctoral research “Arete school”, project No.1.1.1.2/VIAA/1/16/071. 


\section{Introduction}

The vision of a new, ideal person is as old as education. The list of visionaries is long - both the ancient Greeks and Romans, the utopians Campanella and Thomas More, and the activists of the New School movement, the New Man/Overman is also a concept in Nietzsche's philosophy of Übermensch (Prozorov, 2013, p. 210). Social reformers present the New Man as the ideal product of reform and it sells especially well in the field of education, as all education is a story of becoming in a must-be form. For educators, the idea of a New Man is close and exciting, because they always strive to create the ideal from the constantly criticised body of current students. Besides, as Burbules (2016) maintains, the word "new" has magical power, because the new will always be better than the old, the new is "exciting" and "cool" (p. 9). The New Man is also a promising research material for historians, as the New Man embodies the ideals and pedagogical practice of a particular era: for example, the dissatisfaction of decision-makers with educational output so that schools are repeatedly required to create new types of people.

Inevitably, the fabrication of a New Man was integrated in the Soviet school agenda. The New Man project complied with the Bolshevik utopian ideas of destroying the old world after the October Revolution of 1917 and creating a whole new society. The "old" members of society had to be reborn and at the same time had to nurture the New Soviet Man (see Kestere \& Rubene, 2017).

The New Soviet Man has been studied primarily from the perspective of its creators, propagators of Communist ideology (e.g., Kestere \& Rubene, 2017; Svičiulienè, 2016; Kogan, 2011; Savage \& Velikanova, 2011), while the recipients of the New Soviet Man project and its immediate end users, namely pupils and teachers were largely ignored. Hence, the aim of this research is to compare the official concept of the New Soviet Man with the implementation of this concept in educational practice. The research poses two questions as to how the image of the New Soviet Man was presented at schools, and how the concept of the New Soviet Man was perceived and implemented by the "objects" of this state contract - teachers and pupils? 
Though the concept of the New Soviet Man was supposed to refer to both genders, the public discourse in the Soviet Union was men-controlled and the New Soviet Man was to some extent their self-portrait. Likewise, the official texts clearly emphasise the masculine part of that Soviet creature - for example, "Communist morality covers various facets of man [...] as a worthy son of his nation" (Ogorodnikov \& Shimbirev, 1946, p. 56). Therefore, the term "the New Soviet Man" is deliberately used in this study.

\section{Discourses of the New Soviet Man}

The project of the New Soviet Man was not a constant, stagnant concept. It changed with the transformation in the political course of the Communist Party of the Soviet Union and the subsequent campaigning. However, the existing scholarship allows us to identify four stable discourses of the New Soviet Man, following Foucault (1972) terms where discourse is considered as a system of thought, knowledge, or communication which constructs our experience of the world.

The given discourses were established mainly on the basis of the following scholarship: (1) upbringing in the Soviet education system (Kestere \& Krūze, 2013); (2) Prozorov $(2013,2016)$ the concept of biopolitics, which is revealed through the state control exercised by Stalin's power over the bodies of its citizens; (3) Tromly's work on Soviet intelligence in the context of class relations in the USSR (2014), as well as research on the "most valuable" classes as identified by the communist rule (Kestere \& Rubene, 2017); (4) Depaepe’s work $(2009,2012)$ on colonialism, which examines the relationship between colonisers and indigenous people, supported by the studies by Silova (2019) and Silova and Palandjian (2018) on the "nation learning" in the Soviet Empire.

These four discourses of the New Soviet Man remained unchanged and were perpetually rooted in all spheres of Soviet life, declaring certain state requirements in each of them.

\section{Socio-biological Discourse: Gender, Body, Sexuality and Health} The socio-biological discourse focuses on the New Man as a biological being. The body, like everything in the Soviet Union, was no longer the 
property of the individual, either figuratively or often even literally, but was governed, controlled, and regulated by state institutions (Hewitt, 2001, p. 228). The New Soviet Man set off in the land of the Soviets as a vulgar socio-biological concept, when in the spirit of eugenics of the 1920s, the fabrication of the perfect man was planned by coupling ideal communist men and women (Savage \& Velikanova, 2011; Kogan, 2011, p. 165). However, from the 1930s onwards, the concept of a hereditary substance was denied in the USSR (Babkov, 2001), and in 1936, a Communist Party decree banned paedology (Kogan, 2011, p. 167) - a combined pedagogical, psychological and medical approach that emphasised heredity. The ideas of eugenics were put to an end in Soviet public space. However, the state's concern for the body of the New Man did not waver, only its fabrication was refocused from a biological task onto a pedagogical task entrusted to the Communist Party functionaries, scholars and teachers. The body had to be healthy and productive, and it was cared for and looked after by the state (Prozorov, 2013, 2016), supporting and funding regular health check-ups and physical activities (see Kestere, Stonkuvine \& Rubene, 2020). For instance, in 1931 a special state programme was implemented 'Ready for Labour and Defence of the USSR' (GDA) that defined physical condition criteria for all Soviet citizens aged from 10 to 60 . The participation in this programme was mandatory for all USSR pupils until the very collapse of the Soviet empire in 1991.

\section{Social Discourse: Social Class}

This discourse defines the New Man according to the class affiliation, where class becomes a criterion of human value or race, creating obvious associations with the racial theory of Nazism. The flawless "coming from" the working class or the peasantry became the entrance ticket to the Soviet elite, leaving the bourgeoisie and the "rotten" intelligentsia "behind the gate" (see Tromly, 2014). A stamp of class affiliation was affixed to a Soviet pupil in official documents, indicating the occupation of his parents or defining his origin from 'workers', 'farmers' or 'servants', with the last category meaning non-productive workers, including intelligentsia. When the word 'intelligentsia' was mentioned, 
the term 'Soviet' was added to emphasise that a new society had been established in the USSR, which also included this 'non-productive' group. For example, in the 1963 edition of the Soviet Latvia Demographic Report, 'intelligentsia' is named as follows: "[...] Soviet intelligence coming from the depths of the people” (Mežgailis, 1963, p. 113).

\section{Spatial Discourse: Nationality}

This discourse is, in fact, the discourse of colonisation. In colonised societies, the value of a man in the eyes of the power elite grows as he aligns himself with and acquires likeness of colonisers, who are always convinced of the superiority of their culture, language and lifestyle (see Depaepe, 2012; 2009). The New Soviet Man project, using the terminology of colonial studies, also envisaged the "civilising" of colonised nations or indigenous population, making them uniform Soviet citizens, with Russia playing the role of a model, "metropolis" or "elder brother" (see Kelertas, 2006). The blending of the nations living in the territory of the Soviet Union into the Russian-speaking Soviet people was declared in the Communist Party programme of 1961, which provided for the "eradication of national differences, especially language differences” (XXII sjezd [...], 1962, p. 313).

\section{Discourse of Individuality: Personality, Character Traits}

This is the discourse of Soviet morality. The morality of the Soviet man was declared a new type - class morality, but in fact included all the traditional middle-class virtues - helpfulness, modesty, diligence, conscientiousness and kindness.

However, these virtues were framed by hatred. The New Soviet Man had to learn to hate, and his list of enemies was long: the bourgeoisie, the aristocracy, the capitalists, the exploiters, the instigators of war, the nationalists, the chauvinists, the racists, the philistines, the servants of religion, and so on. The Communist Party documents became a means to combat these enemies, and, thus, using Eastwood's (2011) term, "lessons of hatred" entered pedagogical books. For example, a textbook written by Ilyina (1969) and intensively and extensively 
used by Latvian teachers for decades, mentions intolerance four times in relation to the violation of social interests, injustice, social parasitism, unfairness, careerism, and acquisitiveness, racial and national dislike and the enemies of communism (pp.99-106). The essence of Soviet virtue education was clear: "communist virtue must be understood as an action, it calls to fight” (Jesipovs \& Gončarovs, 1948, p. 246).

All four discourses were to materialise in the image of the New Soviet Man, a generalisation of "master fiction” (Calhoun, 2014, p. 27) created and controlled by the ruling regime, an "idealised presentation of themselves to their subordinates” (Scott, 1990, p. 54) - a benchmark to strive for (or pretend to be).

Our study approached the materialisation or representation of the New Soviet Man in theory and practice in three groups of sources: 1) in textbooks, 2) in photographs, and 3) in pupils' profiles. All selected sources cover the period from 1945, when the Soviet occupation returned to Latvia after the WWII, and until 1985, when Gorbachev's perestroika began.

\section{The Propagated Image of the New Soviet Man:}

\section{Textbook Testimonies}

To reconstruct the materialised image of the New Soviet Man, school textbooks, especially primers and readers were analysed, because the primer and the first reader not only teach to read and write but also shape the child's worldview and the value canon (Grever \& Van der Viles, 2017). To paraphrase Foucault, the textbook was another weapon of "normalization" next to teachers in a Soviet school. The textbooks in the Soviet Union were a very effective promulgator of the official state opinion, a guide in sifting "right" from "wrong" shaping the worldview of both teachers and pupils. The wife of the Bolshevik leader Lenin, an ideologist and founder of communistic education Nadezhda Krupskaya (1869-1939) emphasised that textbooks should be based on "large, principal political issues" (Krupskaya, 1931/1959). Hence, clear and evident is the message that the task of the textbooks in Soviet schools is not only providing knowledge but also propagating definite 
political ideology. The watchful eyes of censors followed this performance.

The added value of textbooks is in the pictorial representation of the Soviet Man which accompanied the descriptions of the same. The image often illustrates the generalisation (Burke, 2001, p. 187), as well as sends a "moral message" (Dekker, 2012, p. 49). The Soviet textbooks included the entire Soviet world, and this world was impeccable and correct (Vails \& Geniss, 2006, pp. 77-78). Thus, the image of the New Man in the textbook can be seen as a generalised ideal or role model. The regular repetitiveness of symbols ensures their efficacy (Calhoun, 2014, p. 35), and textbooks were a useful means to sustain this efficacy - the image of the New Man travelled from class to class up the educational ladder.

To identify the image of the New Soviet Man, 26 textbooks published in Riga and available at Georg Eckert Institute for International Textbook Research collection (Braunschweig, Germany) were analysed.

Indeed, the ideal image of the New Soviet Man should be the Leader, who, like a saint or Cinderella, has gone through hardships and as a seasoned man fulfilled the dreams of the people and has acquired an unquestionable authority (see Svičiulienè, 2016). Yet, the Leader could only be worshipped, and it was not possible to reach his heights. The Leader was one and unique, hence, it was necessary to find an earthy model that an ordinary person could match. Therefore, the Soviet people were offered a generalised replica of the Leader, namely, a soldier of the Soviet Army (Lazda, 2005, p. 105, 107). He met well the values propagated in all four discourses of the New Soviet Man: the soldier was healthy and physically well built, otherwise he would not be able to fulfil his duties as a defender of the motherland against internal and external enemies. The soldier belonged to the "right" class, because the army in the Soviet Union was emphatically positioned as a unifier of all classes and groups of society, expressed by the slogan "People and the army are united". The nationality of the soldier did not matter, because the contingent of the Soviet army communicated only in Russian, while the uniform levelled down any social and national differences. A soldier also has all the declared moral qualities - he 
is portrayed in textbooks as brave, disciplined, helpful, modest, he defends the weak and fights against enemies, he is a hero, he is a "real man” (see Citoviča \& Arbitere, 1982, p. 41; Šprunka, 1955, p. 99).

Of the 26 textbooks analysed, 20 (76.9\%) contain texts and pictures that offer a highly positive image of a Soviet army soldier. This construct, namely the soldier, was easy to understand, gave clear guidance for the collective identity (Calhoun, 2014, p. 34) and served perfectly all kinds of propaganda.

The ideal of a man is clear, but what should the New Soviet Man in a female body, as Gradskova (2007) says, be like? The existent scholarship reveals that the role of women in Soviet society was complex and multidimensional: to work like a man and produce a new generation of citizens, while also caring for the family, self-educating and doing sports (see Kestere, Stonkuviene \& Rubene, 2020). "She was glorified for her capacity to work like a man, and at the same time celebrated for her nurturance and her willingness to sacrifice herself for others" (Attwood, 1999, p. 11, 13). The image of a healthy, strong and working mother is communicated by a poem published in a textbook: the author asks, who is a person that cares for a baby with a smile on her lips and song in her voice, that operates a plane, works with the surgeon's knife, knows how to shoot and ski in the snowstorm? Who is the person that always performs her tasks excellently, moves through the path of life securely and proudly in both the sun and rain? (Landa \& Lebedinska, 1947, p. 70). One can find the answer at the end of the poem: this hero is a Soviet woman - the same soldier, only in a woman's body.

\section{Implementation of the New Soviet Man Project at School}

Thus, the state concept of the New Soviet Man was introduced into school classrooms with the help of an intensive and effective tool textbooks. However, to what extend were the pupils and teachers of Soviet Latvia in practice ready to comply with the state request by being reborn in the New Soviet Man and raising him?

The image of the New Soviet Man entered Latvia with the Soviet army in 1940. Latvia - as well as other Baltic States, Estonia and Lithuania were independent countries in the interwar period (1918-1940), but 
were annexed into the Soviet Union in 1940 and remained under Soviet dictatorship until 1991. In each newly acquired territory, the troops are followed by a propaganda team, destroying the symbols and myths of the natives and replacing them with new ones. Likewise, in the territory of the Baltic States, along with the Soviet troops in 1940, intensive Soviet propaganda was launched, whose focus immediately became on the school: "[...] almost all ideological systems, whatever their nature, have tried to impose their values and norms by disciplining individuals through schooling. In this sense, schools were considered powerful instruments in socialising people according to the ideological or political references of the system" (Southwell \& Depaepe, 2019, p. 2). Communist conceptions of world order were made known since childhood and were systematically reinforced throughout one's life, where educational institutions, as disciplinarians of body and spirit, occupied an exceptionally important place. The Soviet school helped to organise and discipline society, taught the individual to assess and control himself (Kogan, 2011, p. 166; Popkewitz, 1988, p. 88).

However, in Soviet Latvia, school classrooms were populated by former residents of free Latvia, and in later years - their descendants, who had grown up with parents' stories about the independent Latvian state. A clash between the Soviet dictatorship's efforts to sovietise the Latvian people and the interests of Latvians to preserve their identity, which was carefully safeguarded in their collective memory, was inevitable. However, Stalin's repression had taught Soviet citizens self-censorship. Since the 1960s, fear no longer dominated people's minds, but considering recent experience, all Latvian families in a public space reminded each other of being cautious (see Abens, 2015).

To reveal how the image of the New Soviet Man propagated in textbooks was adopted in the reality of a Latvian school, the official ambition was compared against unpublished photographs and pupils' graduation reports.

Since 2014, together with students, we have been collecting photos of Soviet pupils in the school environment. There are not many such photographs, because in the 1940s-1980s photography was not a daily occurrence. From a collection of more than 400 photographs, 
256 images were selected for this study. In these photographs, the pupils are in the classroom, and they are undeniably conscious of the camera's and thus the photographer's "eye" - hence, it is a staged event, where the pupils are prepared to be "photographed" and have chosen how to look in the photograph. The pupils are also supervised by the teacher's watchful eye.

Undeniably, the choice of what to do in the official class photograph is limited - the pupils sit on school benches, stand in a group at the blackboard in front of the classroom, write in a notebook, look into a book or listen to the teacher's story. However, the synchronicity of pupils' activities is striking - if they write, everyone does so, if they read - everyone does the same, and the same with other activities. Of the 256 photographs, 203 (79.3\%) attest to all the activities of the pupils being synchronous, the pupils are frozen in a certain position. The pupils are most often seen sitting on benches with their arms crossed on the desk: these are 123 (48.0\%) images out of 256 . When standing upright and holding their hands to the side, pupils are seen in $27(10.5 \%)$ photographs, while 53 photographs (20.7\%) capture the whole class looking into the book, writing or listening to the teacher synchronously. The resemblance to the army is reinforced by the uniforms: everyone is well-groomed, wearing simple and cheap student uniforms and badges of affiliation with children's and youth communist organisations - Red Pioneers and Communist Youth (Komsomol).

The regiment of the New Soviet Man and his subjection to order revealed in the photos, permeated the whole educational process: Soviet pupils followed certain rituals - at the beginning of the lesson they stood up to greet the teacher, spoke only after raising their hands and receiving the teacher's permission, taking occasional walks in the school hallways during the scheduled breaks, and learning army-style marching in special training classes. It can be assumed that the pupils of Soviet Latvia studied "the performance of the other self" (Scott, 1990, p. 33), that is to say, the Soviet pupils trained daily to perform the New Soviet Man-soldier, the role scripted from above.

An assessment of the pupil's conformity to the image of the New Soviet Man was received upon graduation: each graduate of the Soviet 
school received a graduation report, where teachers comprehensively assessed his performance during the school years. The school graduation reports were an important "entrance ticket" to the Soviet universities, where the number of study places was limited.

Among the transcripts and reports available in the Archives of the University of Latvia, a random sample of 367 student reports issued between 1947 and 1984 (ten reports per year) was selected. The school graduation reports were analysed, looking specifically for references to students' moral character.

Each characterisation of a pupil begins with a description of his/her family - parents' occupation, thus revealing the student's social background - for example, "The father is a warehouse keeper at the collective farm X, the mother is a milkmaid at the collective farm X. The family lives in good material conditions" ${ }^{2}$. The report assessed the pupil's health, attitude towards manual work and highlighted success in sports, if any - for example, "General physical development is good. Health is good. [...] Respects any job, loves to work. [...] Does sports" ${ }^{3}$. The report also assessed the pupil's academic performance and involvement in the Communist Youth organization, informing about belonging or non-belonging to this organization in the student's characterization record. The pupil's personality is described in detail, where such character traits as initiative, modesty, joviality, vigour, cooperation and friendliness are praised. The pupil's relationship with the team (collective) and the attitude towards the team are definitely described. Adapting to the team and supporting the interests of the majority is emphasised as a positive virtue.

The most frequently mentioned positive qualities of a Soviet school graduate are the following: responsibility (in $53.1 \%$ of the reports), discipline (38.4\%) and readiness to do manual work (38.4\%). For example, a typical report reads as follows: "An efficient high-performance

2 Secondary school of Latvia. Reference Letter A, 1975. Student's personal files, Fund 1340. University of Latvia Archives, Riga, Latvia, p. 2.

3 Secondary school of Latvia. Reference Letter B, 1969. Student's personal files, Fund 1340. University of Latvia Archives, Riga, Latvia, p. 2. 
team-member. [...] Reads newspapers. Ideologically sound. A Communist Youth member since October 1962. Behaviour is commendable. C. in a team is friendly, accommodating, open, sincere, self-critical. Respects manual work and does it well" ${ }^{4}$. As expected, there were many similarities between the moral characterisation of pupils uncovered in the reports and the official Soviet virtue discourse.

Thus, the characterization reports also show that the Soviet pupils conformed to the propagated image of a soldier, i.e. they were healthy, disciplined, included in the "frame" of the collective and politically educated, they were responsible, diligent and helpful.

\section{Hidden Resistance}

The dictatorship, however, unavoidably engenders the conflict of interests and resistance (Giddens, 1977, p. 348), but oppressors always leave some tiny space for the expression of oppressed interests (Scott, 1990, p. 18). The main task of our research was to identify the openings in the discourse of the oppressors for the expression of the oppressed interests.

Hidden or covert resistance is quiet, undeclared, without confrontation and coordination, without leaders and organizations, not politically articulated. Covert resistance is "non-dramatic", it is integrated into social life and is a part of "normality" (Babicka-Wirkus, 2018, p. 46; Vinthagen \& Johansson, 2013, pp. 2-3, 9). Gestures, facial expressions, clothing and language can betray resistance. Hidden resistance is a system of signs, codes that are visible and understandable only to the inner circle, insiders, but remain invisible, undecoded from the outside - by strangers.

Analysing the covert resistance in the Soviet school environment, the influence of Western culture on Soviet youth, represented by, for example, the images of a hippie in the 1960s and 1970s and the image of a punk in the 1980s was excluded from the focus of the study. It was

4 Secondary school of Latvia. Reference Letter C, 1965. Student's personal files, Fund 1340. University of Latvia Archives, Riga, Latvia, p. 2. 
a clearly displayed counterculture of the youth, passionately opposed by both Soviet officials and teachers. The forms of resistance to school order that exist in any educational setting, such as avoiding wearing a school uniform were likewise excluded from our study. The objective was more intricate - to identify the "coded version of the hidden transcript" (Scott, 1990, p. 18). The three main findings of this research are presented below.

Firstly, the findings are related to the function of the Latvian national costume in the public space, where the national dress became a manifestation against colonisation or Russification understood by the insiders.

In the late 1940 s and early 1950 s, girls put on Latvian national costumes for school graduations. Folk costume was not banned by the Soviet authorities. On the contrary, the old and familiar symbols were transferred to the new political reality, with the Communists hoping that by combining Soviet innovation with tradition, the Soviet model of life would become more agreeable and acceptable to the subjects (Calhoun, 2014, p. 27). Thus, the Latvian national costume was enthusiastically absorbed by the public parades of the Soviet people: for example, in the May 1 procession, women marched dressed in Latvian national costumes with red Soviet flags in their hands (See Petrenko \& Jastržembska, 1955, p. 103; Lubāniete, Bērzāja \& Vuškalne, 1955; Lubāniete, 1949, p. 87).

The Soviet elite saw the Latvian national costume as a mere decoration of the natives. The Latvians, on the other hand, had grown up with the history of this costume, passed down in families from generation to generation: since the Middle Ages the Latvian folk costume has been a testament to the pride of belonging to a marginalised nation. The Latvian folk costume was never worn by, and its meaning was not known to, the "nobility", so the folk costume became a specific code of affiliation, which the "strangers" saw but did not understand (see Kestere, 2020). Under the Soviet dictatorship, the national costume became a manifesto against Russification, which took over Latvia's public space after the World War II: Russian-speaking migrants, including Soviet soldiers, arrived in Latvia from all over the Soviet Union, and the 
number of Latvian schools dramatically decreased: if in 1945 78-79\% of students studied Latvian, then in 1963 their number decreased to 55\% (Bleiere et al., 2005, p. 358).

The wearing of folk costumes at the school graduation festival did not last long - in the late 1950s, "bourgeois nationalism” was condemned (see Prigge, 2015) and, as the photos show, both Latvian and Russian girls were dressed in white dresses and national differences in at least traditional graduation photographs were eliminated. However, Latvian identity codes continued to operate at school. The appearance divided the Latvian and Russian pupils, although both were required to wear the same uniform. The resistance to the visual image was also marked by what "Latvians do not do". Such a daily "lesson in the nationhood" is perfectly described by Silova (2019), telling a story from a Latvian Russian kindergarten, when parents had sent the girl to a photo shoot without a big ribbon in her hair, because these are "worn only by Russians", but the teachers presumed that the girl was not dressed up and duly took care of the situation while the main participant in the event had no idea about these identity struggles.

Yet, Latvians wore national woven decorative ribbons, which are integral to Latvian national costume, and are decorated with one of the oldest and most complex systems of geometric patterns. Only Latvians, never other nationalities, wore these decorative ribbons at school. If in the junior classes the decorative ribbons in combination with the school uniform was most likely the parents' choice, then in the senior classes, the decision to replace the tie with the decorative ribbons for boys and decorating the blouse or hair with the decorative ribbons for girls was already a deliberate manifestation of Latvian identity.

From the research point of view, it is important to note that this detail in pupils' clothing - the decorative ribbon - is recognised as a sign of covert resistance only by those Latvians who grew up in Soviet Latvia. Thus, understanding the details of the context is crucial for identifying covert resistance. If the elements of this resistance were seen and perceived by everyone, then it would no longer be called hidden resistance.

The present research considers the use of folk costume and its elements to be a deliberate, collective form of covert resistance. The use 
of folk culture elements is a well-documented form of collective hidden resistance in Soviet spheres of influence, in particular regarding music and dance (see Loutzaki, 2001; Herzog, 2010; Balogh \& Fülemile, 2008). Clothing behaviour had sometimes become the explicit symbol of resistance to the invaders, as in the case of the 'fustanella' costume, which was worn by the Albanian Royal Guard in interwar period and became a symbol of the Albanian resistance fighters during World War II, or the Georgian folk costume 'Chokha', which symbolizes still nowadays the resistance to Bolshevik Russia's takeover in 1921. But it also has a long story as a way of non-verbal resistance (see Crane, 1999).

Secondly, the research findings concern the moral upbringing of the New Man. Hence, judging by the characterization reports of students, the graduates of the Soviet school conformed to the perfect image of a soldier - they were sporty, disciplined and helpful, they fit well into the team. Although, given the guidelines in the pedagogy textbooks, Soviet pupils also had to be educated in hatred lessons, no single assessment of a student states that the student hates capitalists, bourgeoisie, religious servants, or any other group from a long list of communist enemies. Given how scrupulously the school observed the official Soviet discourse, this discrepancy between propaganda and school practice is striking. Probably hatred and the fight against communist-defined enemies were not really understood, not relevant in practice nor acceptable to both pupils and teachers. Likewise, 'patriotism' and 'internationalism', which were increasingly important virtues in the official discourse, were almost absent in the school graduation reports.

The avoidance of hatred education might be perceived as an unconscious but widespread form of collective hidden resistance.

Thirdly, the findings concern pupils who did not openly violate the rules of the Soviet school, but were "in betweenness", in the Grey Zone (see Pine, 2015), or in the space between open resistance and submission. The appearance of these pupils, as the photos reveal, is not challenging, but they look different. These differences are difficult to define and can only be seen by looking through hundreds and hundreds 
of school photographs. Therefore, the statistical criteria are not applicable and the qualitative description of two photographs would illustrate the claim. For example, in a class photo taken in the late 1940s, all pupils listen synchronously to the teacher's narration, but a girl summons all the attention. She has put on a slightly different blouse than other girls and styled her hair, she has tried to be beautiful and feminine in the poor living conditions of the Soviets. Her image is the absolute opposite of the propagated woman-soldier. Another photo from the 1980s shows a guy who has tried to avoid the Soviet school's strictly declared demand for a short, army-style haircut. From the front, the haircut seems to match what is required, but at the back, the hair is left long. These images suggest an unconscious, individual form of hidden resistance to the image of the New Soviet Man-Soldier.

Further research into covert resistance through gestures, facial expressions, language and silence would be required.

\section{Conclusion}

The creation of the New Soviet Man was a typical educational reform that took place "from above" and satisfied the state's demand for effective, loyal and virtuous citizens. The Communists framed this age-old dream of the ruling elite with their specific demands, namely, the levelling of national differences by blending the common mass of the Soviet people, by hatred education, and by women's social productivity.

In the colonised territories of the Soviet Union, the people were quickly taught that open resistance was pointless and dangerous. Therefore, the "collective show of pretence" (Scott, 1990, p. 34) began. Soviet pupils started playing the role of a New Soviet Man-soldier, and they performed well.

Identification of pupils' hidden resistance specifically against political power is a difficult task, because power games are a daily occurrence in the field of education (see Kestere, Stonkuviene \& Rubene, 2015). The pupils always protest against school order, teachers and adult power in general. However, in Latvia, the power of adults was also the power of strangers, and therefore covert resistance was primarily related to the protection of the culture and national identity acquired 
in the private space (family). The elements of folk culture fit into horizontal solidarity (Scott, 1990, p. 157) and became a collective form of hidden resistance.

Secondly, the Communists' demand for hatred education was likely to cause embarrassment in everyday school practice, and teachers chose to simply ignore it. Besides, the list of enemies announced by the ruling elite did not really coincide with the Latvian views on it. The avoidance became a form of hidden resistance.

Thirdly, slipping into the Grey Zone ("in-betweenness"), which is a symbolic place between the allowed and the forbidden, between two extremely different, anti-polar phenomena became yet another form of hidden resistance. Distinctive nuances in appearance became the Grey Zone between the overtly visible youth counterculture and the uniform solder-like Soviet pupil.

To notice hidden resistance, one must know the context of the Soviet dictatorship very well, because exactly for that reason it was covert and carefully hidden from the eyes of an outsider. Hidden resistance had no purpose, it did not aim at certain results, it merely sought to protect the dignity of the oppressed.

\section{Literature}

ABENS, Aija, 2015. Effects of Authoritarianism on the Teaching of National History: The Case of Latvia. Paedagogica Historica. Vol. 51, No. 1-2, pp. 166-180. ISSN 0030-9230.

ATTWOOD, Lynne, 1999. Creating the New Soviet Woman. Women's Magazines as Engineers of Female Identity, 1922-53. London: Palgrave Macmillan. ISBN 978-0-333-98182-5.

BABICKA-WIRKUS, Anna, 2018. Three-dimensional Model of Resistance in Education. The New Educational Review. Vol. 52, pp. 43-54. ISSN 1732-6729.

BABKOV, Vasilij V., 2001. Medicinskaja genetika v SSSR [Medical Genetics in the USSR]. Vestnik Rossijskoi Akademii Nauk. Vol. 71, No. 10, pp. 928-937.

BALOGH, Balazs \& FÜLEMILE, Ágnes, 2008. Cultural Alternatives, Youth and Grassroots Resistance in Socialist Hungary - The Folk Dance and Music Revival. Hungarian Studies. Vol. 22, No. 1-2, pp. 43-62. Available at: http://real.mtak.hu/38809/1/hstud.22.2008.1-2.4.pdf. 
BLEIERE, Daina et al., 2005. Latvijas vēsture. 20.gadsimts [History of Latvia. 20th Century]. Rīga: Jumava. ISBN-10 9984059790 , ISBN-13 9789984059792.

BURBULES, C. Nicholas, 2016. Technology, Education, and the Fetishization of the 'New'. In: SMEYERS, Paul \& DEPAEPE, Marc (eds.). Educational Research: Discourses of Change and Changes of Discourse. Dordrecht: Springer International Publishing, pp. 9-16. ISBN 978-3-319-30456-4.

BURKE, Peter, 2001. Eyewitnessing. The Use of Images as Historical Evidence. Itaca, New York: Cornell University Press. ISBN 1861890923.

CALHOUN, Gloria, 2014. Saints Into Soviets: Russian Orthodox Symbolism and Soviet Political Posters. Theses. Atlanta: U.S. Georgia State University. History Department. Available at: https://scholarworks.gsu.edu/cgi/ viewcontent.cgi? article $=1089 \&$ context=history_theses.

CITOVIČA, Vera, \& ARBEITERE, Emīlija, 1982. Russkaja recj, 1 klas [Russian for 1st Grade]. Rīga: Zvaigzne.

CRANE, Diana, 1999. Clothing Behaviour as Non-verbal Resistance: Marginal Women and Alternative Dress in the Nineteenth Century. Fashion Theory. Vol. 3, No. 2, pp. 241-268. ISSN 1362-704X (Print), 1751-7419 (Online).

DEKKER, Jeroen, 2012. Mirrors of Reality? The Significance of Image Based Symbol Systems for Research into Long-term Educational Processes. In: SMEYERS, Paul \& DEPAEPE, Marc (eds.). Material Culture and the Representation of Educational Research. Leuven: KU Leuven, pp. 45-56. ISBN 978-3-319-03082-1.

DEPAEPE, Marc, 2009. Belgian Images of the Psycho-Pedagogical Potential of the Congolese during the Colonial Era, 1908-1960. Paedagogica Historica. Vol. 45, No. 6, pp. 707-725. ISSN 0030-9230 (Print), 1477-674X (Online).

DEPAEPE, Marc, 2012. Sometimes a Little Distance is Needed to See What Really Happened: The Study of the Belgian Educational Policy in Congo as an Example of the Critical Vigour of Colonial History of Education. In: Between Educationalization and Appropriation: Selected Writings on the History of Modern Educational Systems. Leuven: Leuven University Press, pp. 222-239. ISBN 13 978-9058679178, ISBN 109058679179.

EASTWOOD, Margaret, 2011. Lessons in Hatred: The Indoctrination and Education of Germany's Youth, The International Journal of Human Rights. Vol. 15, No. 8, pp. 1291-1314. ISSN 1364-2987 (Print), 1744-053X (Online).

FOUCAULT, Michel, 1972. The Archaeology of Knowledge and the Discourse on Language. Translation A. M. Sheridan Smith. New York: Pantheon. ISBN 0-394-71106-8.

GIDDENS, Anthony, 1977/2015. Studies in Social and Political Theory. New York: Basic Books. ISBN 9781138983236. 
GRADSKOVA, Yulia, 2007. Soviet People with Female Bodies: Performing Beauty and Maternity in Soviet Russia in the Mid 1930-1960s. Stockholm. Doctoral Theses. Faculty of Humanities, Department of History. ISBN 978-91-85445-72-1.

GREVER, Maria \& VAN DER VILES, Tina, 2017. Why National Narratives are perpetuated: A Literature Review on New Insights from History Textbook Research. London Review of Education. Vol.15, No. 2, pp. 286-301. ISSN 1474-8479.

HERZOG, Philipp, 2010. "National in Form and Socialist in Content" or Rather "Socialist in Form and National in Content"?: The "Amateur Art System" and the Cultivation of "Folk Art" in Soviet Estonia. Narodna umjetnost-Hrvatski časopis za etnologiju i folkloristiku. Vol. 47, No. 1, pp. 115-140. ISSN 0547-2504 (Print), ISSN 1848-865X (online).

HEWITT, Martin, 2001. Bio-politics and Social Policy: Foucault's Account of Welfare. In: FEATHERSTONE, Mike, HEPWORTH, Mike \& TURNER, S. Bryan (eds.). The Body. Social Process and Cultural Theory. London, Thousand Oaks, New Delhi: Sage publications, pp. 225-255. ISBN 9780803984134.

JESIPOVS, Boriss, \& GONČAROVS, Nikolajs, 1948. Pedagogija: Mācību grāmata pedagoǵiskajām skolām [Pedagogy: a Textbook for Pedagogical Schools]. Rīga: Latvijas valsts izdevniecība.

KELERTAS, Violeta (ed.), 2006. Baltic Postcolonialism. Amsterdam, New York, NY: Rodopi. ISBN 978-90-420-1959-1.

KESTERE, Iveta \& KRŪZE, Aīda (eds.), 2013. History of Pedagogy and Educational Sciences in the Baltic Countries from 1940 to 1990: an Overview. Riga: RaKa. ISBN 978-9984-46-285-1.

KESTERE, Iveta \& RUBENE, Zanda, 2017. Raising the New Soviet (Equal) Man: From Campanella to Krupskaya. Ricerche Pedagogiche. Educatione \& Utopia: Atti del Seminario della S.P.E.C.I.E.S. Vol. 204/205, pp. 59-68. ISSN 1971-5706.

KESTERE, Iveta, 2020. Propaganda comunista y resistancia oculta en las aulas de la Letonia sovetica (1945-1985): Una historia de fotograffas. In: Eulalia Collelldemont, Conrad Vilanou (Coords.). Totalitarismos europeos, propaganda y educaccion. Una historia visual desde los NO-DO. Ediciones Trea, pp. 275-399. ISBN 978-84-18105-29-6.

K,ESTERE, Iveta, STONKUVIENE, Irena \& RUBENE, Zanda, 2015. Introduction: Power - Invisible Architecture of Education. Paedagogica Historica. Vol. 51, No. 1/2, pp. 5-10. ISSN 0030-9230.

KeSTERE, Iveta, STONKUVIENE, Irena \& RUBENE, Zanda, 2020. The New Soviet Man with a Female Body: Mother, Teacher, Tractor Driver... Acta Paedagogica Vilnensia. Vol. 45, pp. 97-109. ISSN 1392-5016. 
KOGAN, Sofya, 2011. Detstvo kak etap formirovanija "Novovo celoveka" $\mathrm{v}$ dovojennom sovetskom oscestve [Childhood as a Stage of Development of the "New Person" in the Soviet Pre-war Society]. Izvestija RGPU im. Gercena. Vol. 150. Available at: http://cyberleninka.ru/article/n/detstvo-kak-etap-formirovaniya-novogo-cheloveka-v-dovoennom-sovetskom-obschestve.

KRUPSKAYA, Nadezda K., 1931/1959. Nationalniy ucebnik [National textbook]. In: Sobranija socinenij [Complete Works]. Moskva. Available at: http://www.detskiysad.ru/ped/ped376.html.

LANDA, Anna \& L,EBEDINSKA, Marija, 1947. English. Anglu valodas mācība vidusskolai [English. English Textbook for Secondary Schools]. Rīga: Latvijas Valsts izdevniecība.

LAZDA, Mara Irene, 2005. Gender and Totalitarianism: Soviet and Nazi Occupations of Latvia (1940-1945). Doctoral Theses. Bloomington. Indiana University. Available at: https://www.worldcat.org/title/gender-and-totalitarianism-soviet-and-nazi-occupations-of-latvia-1940-1945/oclc/69419925.

LOUTZAKI, Irene, 2001. Folk Dance in Political Rhythms. Yearbook for Traditional Music. Vol. 33, pp. 127-137. Available at: https://doi.org/10.2307/1519637.

LUBĀNIETE, Zenta, 1949. Ābece mājmācībai un bērnudārziem [Primer for Home Schooling and Kindergartens]. Rīga: Latvijas Valsts izdevniecība.

LUBĀNIETE, Zenta, BĒRZĀJA, Lidija \& VUŠKALNE, Lidija, 1955. Ābece 1.klasei [Primer for the 1st grade]. Rīga: Latvijas Valsts izdevniecība.

MEŽGAILIS, Bruno, 1963. Padomju Latvijas iedzīvotāji [Residents of Soviet Latvia]. Rīga: Latvijas PSR Zinātṇu akadēmijas izdevniecība.

OGORODNIKOV, Ivan, \& SHIMBIREV, Pavel, 1946. Pedagogika. Ucjebnik dlja ucitelskih institutov [Pedagogy. Textbook for Teacher Training Institutes]. Moskva: Ucpedgiz.

PETRENKO, M. \& JASTRŽEMBSKA, M., 1955. Deutsch. Vācu valoda. Mācību grāmata septingadīgās skolas 5.klasei [German Language. Textbook for the 5th Grade of a Seven-year School]. Rīga: Latvijas Valsts izdevniecība.

PINE, Frances, 2015. Living in the Grey Zones: When Ambiguity and Uncertainly are the Ordinary. In: KNUDSEN, Ida Harboe \& FREDERIKSEN, Martin (eds.). Ethnographies of Grey Zones in Eastern Europe. London: Anthem Press. pp. 25-40. ISBN 9781783084142 (online).

POPKEWITZ, S. Thomas, 1988. Culture, Pedagogy, and Power: Issues in the Production of Values and Colonization. Journal of Education. Vol.170, No. 2, pp. 77-90. Available at: https://doi.org/10.1177/002205748817000204.

PRIGGE, D. William, 2015. Bearslayers: The Rise and Fall of the Latvian National Communists. New York, Bern, Frankfurt, Berlin, Brussels, Vienna, Oxford, Warsaw: Peter Lang. ISBN 978-1-4331-2734-2. 
PROZOROV, Sergei, 2013. Living Ideas and Dead Bodies. The Biopolitics of Stalinism: Ideas and Bodies in Soviet Governmentality. Alternatives: Global, Local, Political. Vol. 38, No. 3, pp. 208-227. Available at: https://doi.org/10.1177/0304375413497844.

PROZOROV, Sergei, 2016. The Biopolitics of Stalinism: Ideology and Life in Soviet Socialism. Edinburgh University Press. ISBN 9781474410533.

SAVAGE, Jon \& VELIKANOVA, Olga, 2011. Re-creating of Mankind: The Philosophy and Actualization of the "New Soviet Man". University of North Texas. Available at: https://digital.library.unt.edu/ark:/67531/metadc84360/.

SCOTT, C. James, 1990. Domination and the Arts of Resistance. New Haven and London: Yale University Press. eISBN 978-0-300-15356-9.

SILOVA, Iveta \& PALANDJIAN, Garine, 2018. Soviet empire, Childhood, and Education. Revista Española de Educación Comparada. Vol. 31, pp. 147-171. ISSN 2174-5382.

SILOVA, Iveta, 2019. Lessons in Everyday Nationhood: Childhood Memories of 'Breaching' the Nation. Children's Geographies, pp. 1-13. ISSN 1473-3285 (print), 1473-3277 (online).

SOUTHWELL, Myriam and DEPAEPE, Marc, 2019. The Relation between Education and Emancipation: Something like Water and Oil? Introducing the Special Issue. Paedagogica Historica. Vol. 55, No. 1, pp. 1-7. ISSN 0030-9230 (print), 1477-674X (online).

ŠPRUNKA, Late, 1955. Latviešu valodas mācība II un III klasei skolās ar krievu mācību valodu [Latvian for 2nd and 3rd Grade for Russian Language School]. Rīga: Latvijas Valsts izdevniecība.

SVIČIULIENĖ, Jūratè, 2016. Soviet Mythology and Propaganda of the 'New' Man. Tarpdalykiniai kultūros tyrimai. Vol. 4, No. 2, pp. 55-65. ISSN 2351-4728.

TROMLY, Benjamin, 2014. Making the Soviet Intelligentsia: Universities and Intellectual Life under Stalin and Khrushchev. Cambridge: Cambridge University Press. ISBN 9781107031104.

VAILS, Pjotrs \& GENISS, Aleksandrs, 2006. 60.gadi. Padomju cilvēka pasaule [1960s World of Soviet People]. Rīga: Jumava. ISBN 9789984381299.

VINTHAGEN, Stellan \& JOHANSSON, Anna, 2013. "Everyday Resistance”: Exploration of a Concept and Theories. Resistance Studies Magazine. Vol. 1. Available at: https://www.yumpu.com/en/rsmag.org.

XXII sjezd Kommunisticeskoj patrtiji Covetskovo Sojuza.17-31 oktabrja 1961 goda. Stenograficeskij otcjot [22nd Congress of the Communist Party of the Soviet Union. October 17-31, 1961. Verbatim Record], 1962. Moskva: Gosudarstvennoje izdatelstvo politiceskoj literaturi. 


\section{Archival materials}

Secondary school of Latvia. Reference Letter A, 1975. Student's personal files, Fund 1340, University of Latvia Archives, Riga, Latvia.

Secondary school of Latvia. Reference Letter B, 1969. Student's personal files, Fund 1340, University of Latvia Archives, Riga, Latvia.

Secondary school of Latvia. Reference Letter C, 1965. Student's personal files, Fund 1340, University of Latvia Archives, Riga, Latvia. 